Editorial

\title{
Seeing the FORESTs for the trees
}

\author{
Helaine Carrer
}

FORESTs is the first tree transcriptome database produced in Brazil. It was created by researchers from Universities and Research Institutes that belong to the Agronomical and Environmental Genomes Project (AEG), a part of the ONSA network created by FAPESP and also included the active participation of four private competing wood and paper companies based in the State of São Paulo. Included in this consortium are Suzano Bahia Sul Papel e Celulose, Votorantim Celulose e Papel, Duratex S/A and Ripasa S/A. It was a challenging and a very productive learning process for scientists and specialists from the private sector to work together, for the first time, on a large genomic project, exchanging experiences to reach a common goal. The main results are now presented in this collection of articles published in this issue of Genetics and Molecular Biology.

The FORESTs database was produced based on Eucalyptus, which is a member of the Myrtaceae family and is composed of more than 700 species (Brooker, 2000). Eucalyptus species mainly originate from Australia and are widely propagated all over the world because they adapt easily to a wide range of environmental conditions. In Brazil, eucalyptus species were introduced by Edmundo Navarro de Andrade for use by the Paulista Railroad Company in the State of São Paulo at the beginning of the XIX Century, and by the time of his death, in 1941, he had established more than 75 species in orchards (Ducrot, 1998). Today, Brazil has the largest area of commercially reforested eucalyptus in the world with around 3 million hectares, representing $60 \%$ of domestically planted forest (FAO). Eucalyptus has become a very commercially important tree, especially for timber, wood and pulp and paper industries. The eucalypts-based forestry industry in Brazil represents around $4 \%$ of gross domestic product and $10 \%$ of exported products (SBS, 2002).

The productivity of managed Eucalyptus forests has increased from $12 \mathrm{~m}^{3} \mathrm{ha}^{-1} \mathrm{yr}^{-1}$ in the $1960 \mathrm{~s}$ to 20-50 $\mathrm{m}^{3} \mathrm{ha}^{-1} \mathrm{yr}^{-1}$ due to improved genetic breeding and

Universidade de São Paulo, Escola Superior de Agricultura "Luiz de Queiroz", Av. Pádua Dias 11, 13418-900 Piracicaba, SP, Brazil. E-mail: hecarrer@carpa.ciagri.usp.br. silviculture. However, the enhancement of several aspects, such as wood quality, by controlling cellulose and lignin biosynthesis and by introducing resistance to biotic and abiotic stress conditions, still pose challenges. The use of genomic approaches to study trees at the molecular level is ready to be intensified by the FORESTs database, which contains 123,889 expressed sequence tags (ESTs) from 25 cDNA libraries prepared from different Eucalyptus grandis organs and tissues, sampled at various developmental stages and stress conditions and seedlings of E. urophylla, E. calmadulensis, E. saligna and E. globulus. E. grandis is the most commonly used species for planting and for breeding crossing with other species and serves as the base tissue sample for the libraries. Eucalypts are diploid plants with a haploid chromosome number of 11 (Eldridge et al., 1993) and a haploid genome size with an average of 500 million base pairs (Mbp) (Grattapaglia and Bradshaw Jr., 1994). The genomic data of the recently completed Populus trichocarpa genome sequence (Brunner et al., 2004), the first tree genome fully sequenced, in addition to the FORESTs database, will provide tree researchers with a remarkable genetic source of genes for understanding tree function. Also, a valuable contribution will come by the sequencing of the E. camaldulensis genome being done at the Kazusa DNA Research Institute in Japan with an expected completion date of 2007, according to the review article by Poke et al. (2005).

This special issue contains valuable articles for presenting a large number of genes identified in the FORESTs database and their putative function in tree metabolic pathways. These results create opportunities for molecular biologists, phytopathologists, wood technologists, plant physiologists and biochemistry researchers to learn more about these trees from the FORESTs database.

\section{References}

Brooker, MIH (2000) A new classification of the genus Eucalyptus L'Her. (Murtaceae). Aust Syst Bot 13:79-148.

Brunner AM, Busov VV and Strauss SH (2004) Poplar genome sequence: functional genomics in an ecologically dominant plant species. Trend Plant Sci 9:49-56. 
Ducrot A (1998) A classificação dos arquivos pessoais e familiares. In: Arquivos Pessoais. Estudos Históricos, Rio de Janeiro 11:151-168.

Eldridge KJ, Davidson C, Harwood and Wyk G van (1993) Eucalypt Domestication and Breeding. Clarendon Press, Oxford, 312 pp.

Food and Agriculture Organization of the United Nations (FAO), www.fao.org/forestry.
Grattapaglia D and Bradshaw Jr HD (1994) Nuclear DNA content of commercially important Eucalyptus species and hybrids. Can J For Res 24:1074-1078.

Poke FS, Vaillancourt RE, Potts BM and Reid JB (2005) Genomic research in Eucalyptus. Genetica 125:79-101

SBS (2002) Florestas plantadas e desenvolvimento sustentável: Geração de empregos, renda e exportações - Diretrizes conceituais. Sociedade Brasileira de Silvicultura, www.sbs.org.br. 